\section{Global burden of disease attributable to diabetes mellitus in Brazil}

\author{
Carga global de doença devida e atribuível ao \\ diabetes mellitus no Brasil
}

\author{
${ }_{1}^{1}$ Escola Nacional de Saúde \\ Pública Sergio Arouca, \\ Fundação Oswaldo Cruz, \\ Rio de Janeiro, Brasil. \\ 2 Coney Island Hospital, \\ New York City Health and \\ Hospitals Corporation, \\ Brooklyn, U.S.A. \\ Correspondence \\ A. F. Oliveira \\ Departamento de \\ Epidemiologia e Métodos \\ Quantitativos em Saúde, \\ Escola Nacional de Saúde \\ Pública Sergio Arouca, \\ Fundação Oswaldo Cruz. \\ Rua Leopoldo Bulhões 1480 , \\ sala 815, Rio de Janeiro, $R J$ \\ 21041-210, Brasil. \\ andreiaf@ensp.fiocruz.br
}

\begin{abstract}
Type II diabetes mellitus accounts for $90 \%$ of all cases of diabetes, and its inclusion in health evaluation has shown that its complications have a considerable impact on the population's quality of life. The current article presents the results of the Global Burden of Disease Study in Brazil for the year 1998, with an emphasis on diabetes mellitus and its complications. The indicator used was disability-adjusted life years (DALY), using a discount rate of 3\%. In Brazil, ischemic heart disease, stroke, and diabetes accounted for 14.7\% of total lost DALYs. Brazil showed a higher proportion of years lived with disability (YLDs) among total DALYs for diabetes as compared to other countries. Retinopathy and neuropathy were the complications that contributed most to YLDs. According to forecasts, diabetes mellitus will have an increasing impact on years of life lost due to premature death and disability in the world, shifting from the $11^{\text {th }}$ to $7^{\text {th }}$ cause of death by 2030. It is thus urgent to implement effective measures for prevention, early diagnosis, counseling, and adequate follow-up of patients with diabetes mellitus.
\end{abstract}

Diabetes Mellitus; Potential Years of Life Lost; Cost of Illness

\author{
Andreia Ferreira de Oliveira ${ }^{1}$ \\ Joaquim Gonçalves Valente 1 \\ Iuri da Costa Leite 1 \\ Joyce Mendes de Andrade Schramm 1 \\ Anne S. Renteria de Azevedo 2 \\ Angela Maria Jourdan Gadelha 1
}

\section{Introduction}

Diabetes mellitus is a worldwide public health problem and one of the main chronic syndromes currently affecting humankind, regardless of socioeconomic status and geographic location. The syndrome has a multiple etiology, resulting from lack of insulin and/or the inability of insulin to adequately exert its effects. Diabetes mellitus is characterized by chronic hyperglycemia, frequently accompanied by dyslipidemia, arterial hypertension, and endothelial dysfunction 1.

Diabetes is classified in two main types: type I, which appears most frequently during childhood or adolescence; and type II, related to obesity and physical inactivity. Type II diabetes mellitus accounts for approximately $90 \%$ of all cases of diabetes and occurs most frequently after 40 years of age 2,3 .

Various factors are associated with increased prevalence of diabetes mellitus in recent decades, including the increase in population life expectancy, along with growing intake of saturated fat, physical inactivity, and obesity 4,5,6,7. Other factors like progressive urbanization, leading to changes in lifestyle and cultural habits and stress in large cities, have been identified as triggering factors for diabetes in individuals with genetic susceptibility 8,9,10. The inclusion of chronic noncommunicable diseases, especially diabetes, in the current health profile of populations is extremely relevant in light of estimates by the World 
Health Organization (WHO) that non-communicable diseases currently account for $58.5 \%$ of all deaths and $45.9 \%$ of the global burden of disease, as expressed by disability-adjusted life years (DALYs) 4 .

According to estimates, in 1995 diabetes mellitus affected $4 \%$ of the world's adult population, while by 2025 this proportion may increase to $5.4 \%$, or approximately 300 million people. The largest share of this increase will occur in developing countries, which is expected to show the same current pattern of concentration of cases in the 45-64-year age group 10,11,12.

In Brazil, the most comprehensive study on diabetes mellitus prevalence was conducted in 1988, in nine State capitals. Estimated prevalence was $7.5 \%$ in individuals $30-69$ years of age, with the highest prevalence (17.4\%) in the 60-69-year age group 13 .

Studies suggest that diabetics are two to four times more likely to die of heart disease (as compared to non-diabetics), and four times more likely to present peripheral vascular disease and stroke $14,15,16,17,18,19$. Some $30 \%$ of patients in peritoneal dialysis, hemodialysis, and transplant programs in the United States are diabetics 20, and $50 \%$ of non-trauma amputations in the United States are in diabetics 21,22. According to WHO estimates, 15 years after onset of the disease, $2 \%$ of diabetics have developed blindness and 10\% severe visual impairment. Additionally, 30-45\% display some degree of retinopathy, $10-20 \%$ nephropathy, 20-35\% neuropathy, and 10-25\% cardiovascular disease 10,11.

Meanwhile, studies have shown a strong association between various non-communicable diseases like cardiovascular diseases, respiratory diseases, and diabetes and a relatively small set of risk factors, especially smoking, excess alcohol consumption, overweight, hypertension, hypercholesterolemia, low consumption of fruit and vegetables, and physical inactivity 23 .

The current article presents the results of the Global Burden of Disease Study in Brazil for the year 1998 with an emphasis on diabetes mellitus and its complications as the most important cause of healthy years of life lost to premature death or disability in the country (available at http://www.ensp.fiocruz.br/projetos/carga/ apresentacao.htm).

\section{Material and methods}

The Global Burden of Disease Study in Brazil was conducted by the National School of Public Health, Oswaldo Cruz Foundation (ENSP/ FIOCRUZ) from 2000 to 2002. The study was approved by the Research Ethics Committee of the ENSP/FIOCRUZ, under protocol number $42 / 2001$. In this study, the methodology developed by Murray \& Lopez 24 was adapted to the Brazilian context, aiming to establish the dimension of relevant health problems for the country as well as for each of its five major regions.

The indicator used in these studies was the DALY, which extends the concept of potential years of life lost due to premature death (Murray \& Lopez ${ }^{24)}$ to include equivalent years of healthy life lost due to health problems or disability. The number of DALYs was calculated by the sum of the two portions: years of life lost due to premature death (years of life lost - YLL) and years of life lost due to disability (years lived with disability - YLD).

An important concept incorporated into each of the two DALY components is the discount rate 25,26 , which refers to the practice of assigning a lower value to years of life lost in the future as compared to the present 27 . For the purposes of the Global Burden of Disease Study, a panel of health cost-effectiveness experts recommended a $3 \%$ discount rate 28 .

Global burden of disease studies classify the causes of years of life lost to premature death or disability in three major groups: Group I, which includes infectious and parasitic diseases, maternal causes, perinatal causes, and nutritional deficiencies; Group II, chronic non-communicable diseases; and Group III, external causes. These three major groups are subdivided into subgroups, for example Group II is subdivided into II.C - diabetes mellitus, among other subdivisions. In all, this study covered 113 diseases or health problems.

The mortality data used to estimate YLL are from the national Mortality Information System/ Unified National Health System (SIM/SUS). For the Global Burden of Disease Study in Brazil, specific procedures were adopted in the mortality component, including three phases: (a) correction for under-recording of deaths; (b) reallocation of garbage codes; and (c) redistribution of illdefined signs, symptoms, and conditions (chapter XVIII of the $10^{\text {th }}$ Revision of the International Classification of Diseases - ICD-10 29).

For morbidity (YLD), specific clinical/epidemiological parameters were collected from a number of data bases as well as from the scientific literature in order to provide estimates, particularly of incidence and duration, which are used in the formula to calculate the YLD by cause of disease, sex, age group, and geographic region of the country.

In the case of diabetes mellitus, the number of YLD was calculated for diabetes cases and sequel- 
ae, like retinopathy, amputation, and neuropathy. Estimates included uncomplicated cases of diabetes, diabetic neuropathy, retinopathy with moderate loss of vision, retinopathy with blindness (severe loss of vision), amputation (toes, ankle, foot, leg, and thigh) and diabetic foot.

A public-domain software called DISMOD II (Barendregt J. Department of Public Health, Erasmus University, Rotterdam, Netherlands), was used to estimate unavailable parameters and ensure the consistency of available information, estimating the final parameters for the respective diseases.

Future scenarios were taken into consideration to project the global burden of disease, so as to evaluate the future impacts of diseases and other health problems on the Brazilian population. The methodology was based on the description of mortality rate tendencies and their extrapolation as described by Leite et al. ${ }^{30}$.

Since data are scarce on type I diabetes mellitus in Brazil and prevalence is low, cases of diabetes and sequelae were only modeled for type II diabetes mellitus. Cases of chronic renal failure secondary to diabetes were included among renal diseases, as recommended by the authors of global burden of disease studies 31 and were not the object of analysis in the current study.

Table 1 provides a summary of the main information raised through a systematic literature review on the clinical/epidemiological parameters used to estimate the DALYs for each complication or sequelae related to diabetes mellitus.

\section{Results}

Table 2 shows the mortality rates and the absolute number of YLLs, YLDs, and DALYs according to major groups of causes and diabetes mellitus by sex. Group II accounts for a large share of the total estimated disease burden, with $66.3 \%$ of the DALYs. Groups I and III accounted for $23.5 \%$ and $10.2 \%$, respectively. Diabetes showed mortality rates ranging from 0.2 e 0.3 per thousand inhabitants and accounted for $5.1 \%$ of the estimated DALYs (6\% for women and $4.4 \%$ for men). The proportion of YLD in DALY is a much higher percentage than the proportion of YLL in DALY: $73.4 \%, 71.6 \%$, and $72.5 \%$ for men, women, and both sex, respectively (Tabela 3 ).

Figure 1 shows the share of diabetes mellitus in total DALYs by sex, age, and major region of the country. As shown, there was no marked difference by sex. However, age plays an important role in terms of DALYs, with a high burden of disease for diabetes mellitus in the 45-59 and 60-69-year age brackets. Importantly, one cannot ignore the impact of diabetes mellitus on the latter two age groups, given that based on the methodology used in burden of disease studies, the older individuals are, the less they lose in terms of DALYs.

Unlike other regions of Brazil, in the Northeast a large share of total DALYs lost to diabetes were in the mortality component (YLL) (Table 3).

Table 3 shows diabetes mellitus sequelae by sex for Brazil as a whole and by region. Diabetic retinopathy and neuropathy were relevant consequences of the disease and underlying causes of loss of quality of life in all regions of the country. The national average was $24.7 \%$ of all YLD from diabetes mellitus due to retinopathy, with the highest proportion observed in the North $(28.2 \%)$ and the lowest in the Northeast (18.7\%). For diabetic neuropathy, the proportion varied from $11.4 \%$ in the Northeast to $13.4 \%$ in the Southeast (Table 3).

Table 4 shows the four principal causes of lost DALYs in Brazil according to sex and the projection of these diseases for the year 2013. Diabetes mellitus was the leading cause of lost DALYs for both sexes in 1998 and is estimated to remain in the same position in 2013, with an increase of $29.6 \%$ in 15 years. The largest proportional increase in relation to 1998 (35.1\%) is projected for men, with diabetes mellitus moving from fourth to second cause by 2013 .

\section{Discussion}

In the European Global Burden of Disease Study in 2000, cardiovascular diseases, cancer, and diabetes accounted for approximately $32 \%$ of total DALYs ${ }^{32}$. In burden of disease studies in Australia and the Netherlands 33,34, ischemic heart disease/stroke and diabetes mellitus accounted for $20.8 \%$ and $20.3 \%$ of total DALYs, respectively. In Brazil, the proportion is $14.7 \%$ for the combination of ischemic heart disease, stroke, and diabetes (data not shown).

Analyzing the share of diabetes mellitus in total DALYs due to all causes, in the 1990 Global Burden of Disease Study, diabetes accounted for $1.4 \%$ of total DALYs in Latin America and the Caribbean ${ }^{31}$. However, in the 1994 Global Burden of Disease Study in the Netherlands, the share was $3.4 \% 34$. In 2001 , in the developed countries, diabetes mellitus accounted for $2.8 \%$ of total lost DALYs 35 .

Results similar to those found in the current study (5.1\%) were observed in the Global Burden of Disease Study in Australia in 1996, where the share was approximately $5 \%$ for men and women combined, and also for men and women separately 33 . 
Parameters used to estimate disability-adjusted life years (DALYs) for each complication or sequelae related to diabetes mellitus. Brazil, 1998.

\begin{tabular}{|c|c|c|c|c|c|c|}
\hline & $\begin{array}{c}\text { Uncomplicated } \\
\text { cases }\end{array}$ & Amputations & $\begin{array}{c}\text { Retinopathy with } \\
\text { moderate loss of vision }\end{array}$ & $\begin{array}{l}\text { Retinopathy with } \\
\text { blindness }\end{array}$ & $\begin{array}{c}\text { Diabetic } \\
\text { neuropathy }\end{array}$ & $\begin{array}{l}\text { Diabetic } \\
\text { foot }\end{array}$ \\
\hline Definition & $\begin{array}{l}\text { Syndrome with a } \\
\text { multiple etiology } \\
\text { resulting from lack of } \\
\text { insulin and/or } \\
\text { inability of insulin to } \\
\text { produce its effects } 1\end{array}$ & $\begin{array}{l}\text { Hospitalization form } \\
\text { included amputation } \\
\text { at the level of the } \\
\text { ankle, foot, knee, } \\
\text { toe, or thigh }\end{array}$ & $\begin{array}{l}\text { Great difficulty in } \\
\text { reading small print in } \\
\text { newspapers or difficulty } \\
\text { in recognizing faces } \\
\text { at } 4 \text { meters distance. } \\
\text { Visual acuity } \\
\text { ranging from } 20 / 80 \\
\text { to } 20 / 160 \text { using } \\
\text { prescription eyeglasses }\end{array}$ & $\begin{array}{l}\text { Individuals incapable } \\
\text { of reading, with } \\
\text { great difficulty } \\
\text { recognizing persons } \\
\text { at } 4 \text { meters distance. } \\
\text { Visual acuity less than } \\
\text { or equal to } 20 / 200 \\
\text { using prescription } \\
\text { eyeglasses }\end{array}$ & $\begin{array}{l}\text { Presence of signs } \\
\text { or symptoms of } \\
\text { neurological } \\
\text { dysfunction in } \\
\text { patients with } \\
\text { diabetes mellitus } \\
\text { after excluding } \\
\text { other causes }\end{array}$ & $\begin{array}{l}\text { Consequence of } \\
\text { coexistence of } \\
\text { vascular } \\
\text { insufficiency and } \\
\text { neuropathy } 47,48 \text { * }\end{array}$ \\
\hline Incidence & $\star *$ & $\begin{array}{l}\text { Total cases } \\
\text { hospitalized in } \\
\text { the year } 2000\end{array}$ & $\begin{array}{l}\text { After } 10 \text { years of } \\
\text { evolution, } 58 \% \text { of } \\
\text { incident cases of } \\
\text { diabetes develop } \\
\text { retinopathy } 49 \star \star \star\end{array}$ & * & & $\begin{array}{l}\text { After } 15 \text { years of } \\
\text { evolution, } 55.5 \% \\
\text { present peripheral } \\
\text { vascular disease } \\
\text { (diabetic foot) } 50\end{array}$ \\
\hline Prevalence & $\begin{array}{c}\text { Parameters based } \\
\text { on last national } \\
\text { survey } 51\end{array}$ & $\begin{array}{l}\text { Incidence } \\
\text { multiplied } \\
\text { by duration }\end{array}$ & $\begin{array}{l}\text { After } 10 \text { years of } \\
\text { evolution, present in } \\
58 \% \text { of prevalent cases } \\
\text { of diabetes, as mild } \\
\text { or moderate } 49 \star \star \star\end{array}$ & $\begin{array}{l}\text { Prevalence zero } \\
\text { up to } 29 \text { years, } \\
\text { and } 2.1 \% \text { of } \\
\text { blindness among } \\
\text { diabetics } 30 \text { years } \\
\text { or older } 52\end{array}$ & $\begin{array}{l}\text { Based on odds of } \\
\text { prevalent cases of } \\
\text { diabetic neuropathy } \\
\text { and diabetes } \\
\text { cases estimated } \\
\text { n countries with } \\
\text { established market } \\
\text { economies } 31 \text { \# }\end{array}$ & $\star \star$ \\
\hline Duration & $\begin{array}{r}\text { Parameters from } \\
\text { Burden of Di }\end{array}$ & $\begin{array}{l}\text { Australian Global } \\
\text { ease Study } 33\end{array}$ & $\begin{array}{l}\text { Duration of case } \\
\text { from modeling }\end{array}$ & $\begin{array}{l}\text { es of uncomplicated dia } \\
\text { with the DISMOD II sof }\end{array}$ & $\begin{array}{l}\text { Detes resulting } \\
\text { tware for Brazil }\end{array}$ & $\begin{array}{c}0.2 \text { years } 31 \text { or } \\
\text { estimates from } \\
\text { DISMOD II software } \\
\text { for Australia } 33\end{array}$ \\
\hline Remission & & & ** & & Zero & $\star \star$ \\
\hline Relative risk & & 5.053 & 2.053 & 2.053 & 2.053 & 2.053 \\
\hline Mortality & SIM/SUS & & & DISMOD II & & \\
\hline $\begin{array}{l}\text { Proportion of } \\
\text { treatment }\end{array}$ & $\begin{array}{l}27.5 \% \text { of } \\
\text { patients treated }\end{array}$ & & & $\star \star$ & & \\
\hline
\end{tabular}

SIM/SUS: Mortality Information System/Unified National Health System.

* Principal complications: ulcers, gangrene, chronic sensory-motor neuropathy, autonomic neuropathy, peripheral vascular disease, repetitive painless fractures (Charcot joints), abnormal proprioception, and diabetic mononeuropathy. The International Classification of Diseases, 10th Revision (ICD-10) 29 codes were defined for diabetic foot (listed above), which in some cases included ICD-10 codes already selected for diabetic neuropathy, since the two complications are not mutually exclusive;

** Parameters not used;

*** As a function of advanced age, it was assumed that only $30 \%$ of the incident cases in the last age group would develop the disease;

\# These values were applied to the total prevalence of diabetes estimated by the Global Burden of Disease Study for Brazil 31 , obtaining the estimated prevalence of diabetic neuropathy in Brazil in 1998. We opted to use the data from the global burden of disease/established market economies and not Latin America, because for chronic non-communicable diseases like diabetes, the epidemiological transition in Brazil is more consistent with the pattern in First World countries. 
Mortality rate, absolute number, and percentage of all-cause and diabetes mellitus years of life lost (YLL), years lived with disability (YLD) and disability-adjusted life years (DALYs), according to sex. Brazil, 1998.

\begin{tabular}{|c|c|c|c|c|c|c|c|}
\hline Gender/Specification & Mortality rate * & Number of YLL & YLLs/DALYs & Number of YLD & YLD/DALYs & Number of DALYs & Total DALYs (\%) \\
\hline \multicolumn{8}{|l|}{ Male } \\
\hline All causes & 8.1 & $10,996,759$ & 54.4 & $9,224,311$ & 45.6 & $20,221,071$ & 100.0 \\
\hline Group I & 1.6 & $2,842,218$ & 65.2 & $1,519,743$ & 34.8 & $4,361,962$ & 21.6 \\
\hline Group II & 5.3 & $5,797,516$ & 45.3 & $6,997,201$ & 54.7 & $12,794,717$ & 63.3 \\
\hline Diabetes mellitus & 0.2 & 235,897 & 26.6 & 651,105 & 73.4 & 887,002 & 4.4 \\
\hline Group III & 1.2 & $2,357,025$ & 76.9 & 707,366 & 23.1 & $3,064,392$ & 15.2 \\
\hline \multicolumn{8}{|l|}{ Female } \\
\hline All causes & 5.9 & $7,034,511$ & 40.7 & $10,262,656$ & 59.3 & $17,297,168$ & 100.0 \\
\hline Group I & 1.2 & $2,098,198$ & 47.2 & $2,345,053$ & 52.8 & $4,443,251$ & 25.7 \\
\hline Group II & 4.5 & $4,513,813$ & 37.4 & $7,558,954$ & 62.6 & $12,072,767$ & 69.8 \\
\hline Diabetes mellitus & 0.3 & 295,588 & 28.4 & 746,773 & 71.6 & $1,042,360$ & 6.0 \\
\hline Group III & 0.2 & 422,501 & 54.1 & 358,649 & 45.9 & 781,150 & 4.5 \\
\hline \multicolumn{8}{|l|}{ Both sexes } \\
\hline All causes & 7.0 & $18,031,271$ & 48.1 & $19,486,968$ & 51.9 & $37,518,239$ & 100.0 \\
\hline Group I & 1.4 & $4,940,416$ & 56.1 & $3,864,796$ & 43.9 & $8,805,213$ & 23.5 \\
\hline Group II & 4.9 & $10,311,329$ & 41.5 & $14,556,156$ & 58.5 & $24,867,484$ & 66.3 \\
\hline Diabetes mellitus & 0.3 & 531,485 & 27.5 & $1,397,878$ & 72.5 & $1,929,362$ & 5.1 \\
\hline Group III & 0.7 & $2,779,526$ & 72.3 & $1,066,016$ & 27.7 & $3,845,541$ & 10.2 \\
\hline
\end{tabular}

* Mortality rate per 1,000 inhabitants.

Mortality due to diabetes does not reflect the entire magnitude of the burden resulting from the disease, since a large share of individuals present long-term complications and thus account for an important proportion of the morbidity (YLD).

In relation to the YLL and YLD components in the more overall context of total DALYs for diabetes, in Australia a high percentage was due to morbidity: $58.4 \%, 59.3 \%$, and $57.4 \%$ for both sexes combined, men, and women, respectively 33 . Similar results were observed in the Global Burden of Disease Study in the Netherlands for both sexes $(60.5 \%)$ 34. The share of the YLD component was higher in the present study: $72.5 \%, 73.4 \%$, and $71.6 \%$ for the total, men, and women, respectively.

The higher share of YLDs in total DALYs for diabetes mellitus in Brazil as compared to other countries (Australia and the Netherlands) may be due to the existence of numerous sub-clinical cases $(30-50 \%$ of all cases in most populations) and often with an apparently benign clinical course, with silent onset and late complications. Diabetes mellitus jeopardizes the lives of a huge contingent of individuals, leading to permanent reduction in their quality of life 2 .

As for the proportional share of diabetes mellitus in Group II and according to age group, there was an important increase in the proportional distribution of DALYs lost to diabetes mellitus in Group II in the 45-59 and 60-69 year age groups.

The Global Burden of Disease Study in Australia 33 also showed an increasing share of diabetes in the wider context of Group II when comparing the 15-34 and 35-54-year age brackets, among men ( $1 \%$ and $6.6 \%$, respectively) and women (1.7\% and 5.5\%, respectively). A smaller increase was also observed in the 1990 Global Burden of Disease Study for the entire world 31 , with proportions of $1.3 \%$ and $2.7 \%$ for the $15-44$ and $45-59$ year brackets among men and $1.3 \%$ and $3.6 \%$, respectively, for the same age brackets in women.

Among the principal complications of diabetes, retinopathy $(24.7 \%)$ and neuropathy (12.8\%) contributed the most to the morbidity component (YLD). These results were similar to those for diabetic neuropathy in the Australian study ${ }^{33}$, in which $9.6 \%$ of the total YLDs due to diabetes were associated with this sequela. For retinopathy, the proportion in Australia (13\%) was lower than in Brazil (24.7\%).

Forecasts indicate a growing impact of diabetes mellitus as a relevant cause of years of life lost to premature death and disability by 2013 and point to the need for specific health measures aimed at reducing its future prevalence, with the 
Figure 1

Proportional distribution of disability-adjusted life years (DALYs) lost to diabetes mellitus in Group II, non-communicable diseases by sex, age, and major geographic areas of Brazil, 1998.

1a) Males

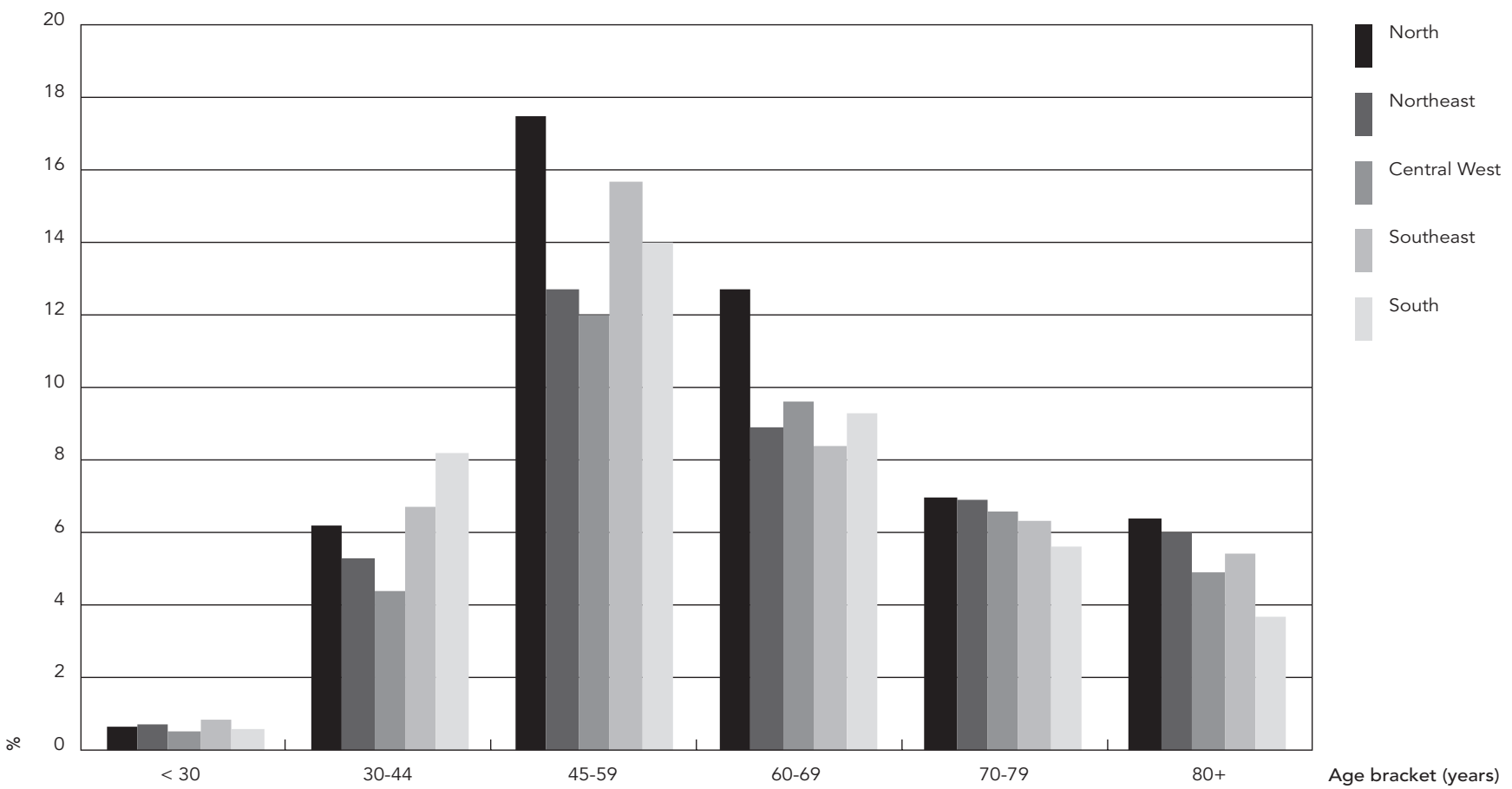

1b) Females

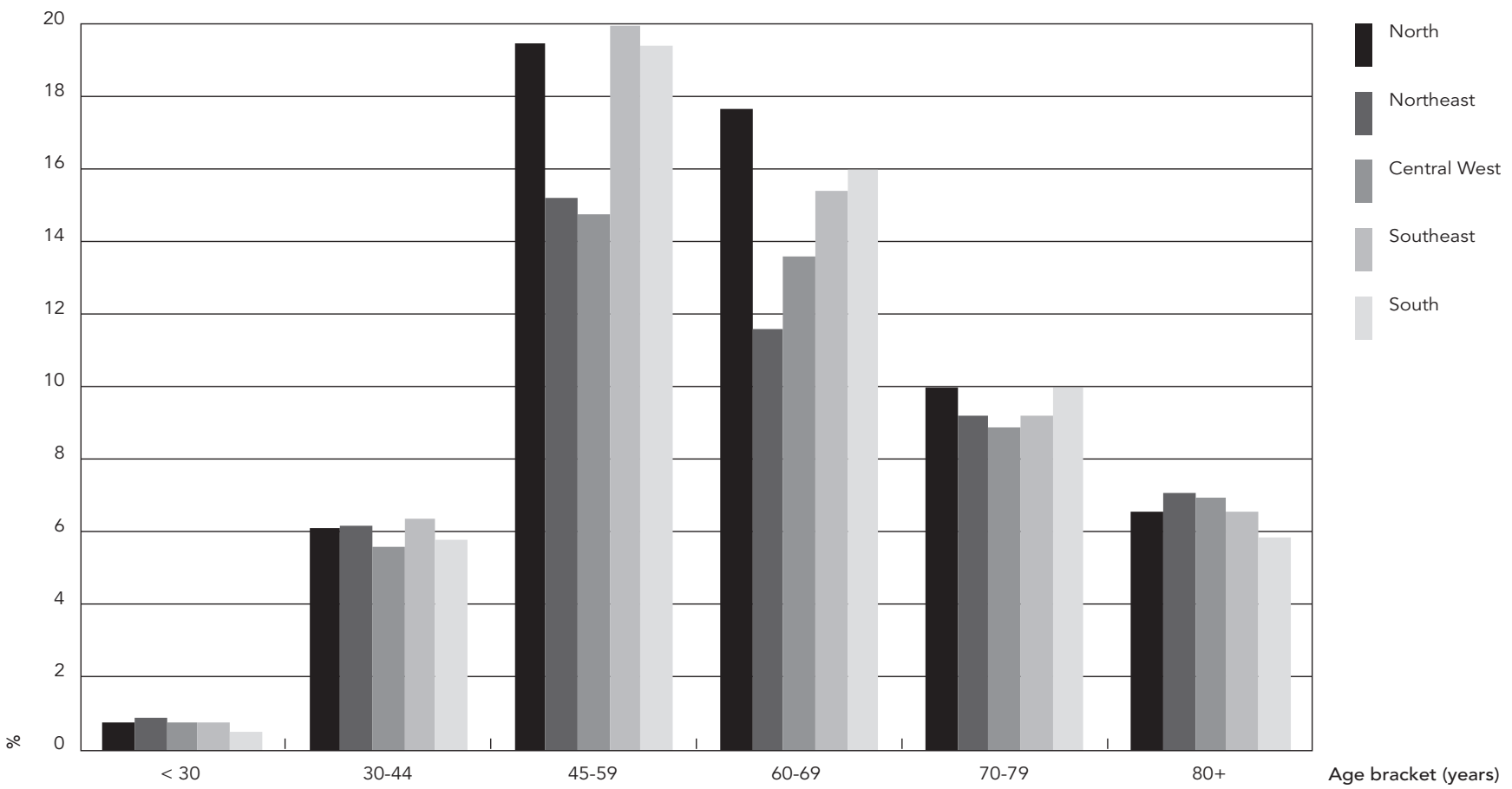


Number of deaths, years of life lost (YLL), years lived with disability (YLD), and disability-adjusted life years (DALYs), and proportional distribution of YLL and YLD according to groups of sequelae of diabetes mellitus among total DALYs, by sex and major geographic regions of Brazil, 1998.

\begin{tabular}{|c|c|c|c|c|c|c|c|c|c|c|c|c|}
\hline \multirow{2}{*}{$\begin{array}{l}\text { Gender/ } \\
\text { Disease categories }\end{array}$} & \multicolumn{2}{|c|}{ North } & \multicolumn{2}{|c|}{ Northeast } & \multicolumn{2}{|c|}{ Central West } & \multicolumn{2}{|c|}{ Southeast } & \multicolumn{2}{|c|}{ South } & \multicolumn{2}{|c|}{ Brazil } \\
\hline & Number & $\%$ & Number & $\%$ & Number & $\%$ & Number & $\%$ & Number & $\%$ & Number & $\%$ \\
\hline \multicolumn{13}{|l|}{ Male } \\
\hline Number of deaths & 821 & & 7,090 & & 843 & & 7,165 & & 2,145 & & 18,064 & \\
\hline Total YLL & 10,961 & 20.6 & 87,183 & 40.4 & 11,641 & 27.3 & 97,890 & 22.4 & 28,221 & 20.5 & 235,897 & 26.6 \\
\hline Total YLD & 42,329 & 79.4 & 128,467 & 59.6 & 30,991 & 72.7 & 339,831 & 77.6 & 109,487 & 79.5 & 651,105 & 73.4 \\
\hline YLD (cases) & 16,874 & 31.7 & 50,895 & 23.6 & 12,213 & 28.6 & 141,347 & 32.3 & 45,753 & 33.2 & 267,081 & 30.1 \\
\hline YLD (diabetic foot) & 200 & 0.4 & 510 & 0.2 & 145 & 0.3 & 1,863 & 0.4 & 678 & 0.5 & 3,397 & 0.4 \\
\hline YLD (neuropathy) & 6,378 & 12.0 & 24,464 & 11.3 & 4,947 & 11.6 & 55,700 & 12.7 & 17,851 & 13.0 & 109,340 & 12.3 \\
\hline YLD (blindness) & 2,886 & 5.4 & 9,236 & 4.3 & 2,651 & 6.2 & 23,140 & 5.3 & 7,420 & 5.4 & 45,333 & 5.1 \\
\hline YLD (retinopathy) & 15,921 & 29.9 & 42,650 & 19.8 & 11,017 & 25.8 & 114,452 & 26.1 & 37,487 & 27.2 & 221,527 & 25.0 \\
\hline YLD (amputation) & 69 & 0.1 & 712 & 0.3 & 18 & 0.0 & 3,330 & 0.8 & 298 & 0.2 & 4,427 & 0.5 \\
\hline Total DALYs & 53,290 & 100.0 & 215,650 & 100.0 & 42,632 & 100.0 & 437,722 & 100.0 & 137,708 & 100.0 & 887,002 & 100.0 \\
\hline \multicolumn{13}{|l|}{ Female } \\
\hline Number of deaths & 1,121 & & 10,302 & & 1,112 & & 10,088 & & 3,111 & & 25,734 & \\
\hline Total YLL & 13,925 & 25.7 & 114,327 & 44.2 & 14,354 & 29.4 & 117,756 & 22.8 & 35,226 & 21.4 & 295,588 & 28.4 \\
\hline Total YLD & 40,267 & 74.3 & 144,149 & 55.8 & 34,467 & 70.6 & 398,180 & 77.2 & 129,709 & 78.6 & 746,773 & 71.6 \\
\hline YLD (cases) & 15,900 & 29.3 & 57,318 & 22.2 & 13,496 & 27.6 & 162,342 & 31.5 & 52,364 & 31.7 & 301,419 & 28.9 \\
\hline YLD (diabetic foot) & 181 & 0.3 & 525 & 0.2 & 125 & 0.3 & 1,842 & 0.4 & 772 & 0.5 & 3,445 & 0.3 \\
\hline YLD (neuropathy) & 6,908 & 12.7 & 29,759 & 11.5 & 5,655 & 11.6 & 72,425 & 14.0 & 22,251 & 13.5 & 136,998 & 13.1 \\
\hline YLD (blindness) & 2,655 & 4.9 & 9,859 & 3.8 & 2,557 & 5.2 & 23,479 & 4.6 & 7,396 & 4.5 & 45,947 & 4.4 \\
\hline YLD (retinopathy) & 14,416 & 26.6 & 46,152 & 17.9 & 12,623 & 25.9 & 135,930 & 26.3 & 46,774 & 28.4 & 255,895 & 24.5 \\
\hline YLD (amputation) & 208 & 0.4 & 535 & 0.2 & 10 & 0.0 & 2,162 & 0.4 & 151 & 0.1 & 3,067 & 0.3 \\
\hline Total DALYs & 54,192 & 100.0 & 258,476 & 100.0 & 48,821 & 100.0 & 515,936 & 100.0 & 164,935 & 100.0 & $1,042,360$ & 100.0 \\
\hline \multicolumn{13}{|l|}{ Both sexes } \\
\hline Number of deaths & 1,942 & & 17,392 & & 1,955 & & 17,253 & & 5,256 & & 43,798 & \\
\hline Total YLL & 24,886 & 23.2 & 201,510 & 42.5 & 25,995 & 28.4 & 215,646 & 22.6 & 63,447 & 21.0 & 531,485 & 27.5 \\
\hline Total YLD & 82,596 & 76.8 & 272,616 & 57.5 & 65,458 & 71.6 & 738,012 & 77.4 & 239,196 & 79.0 & $1,397,878$ & 72.5 \\
\hline YLD (cases) & 32,773 & 30.5 & 108,213 & 22.8 & 25,708 & 28.1 & 303,689 & 31.8 & 98,117 & 32.4 & 568,501 & 29.5 \\
\hline YLD (diabetic foot) & 381 & 0.4 & 1,035 & 0.2 & 270 & 0.3 & 3,706 & 0.4 & 1,450 & 0.5 & 6,842 & 0.4 \\
\hline YLD (neuropathy) & 13,286 & 12.4 & 54,223 & 11.4 & 10,603 & 11.6 & 128,124 & 13.4 & 40,102 & 13.3 & 246,338 & 12.8 \\
\hline YLD (blindness) & 5,541 & 5.2 & 19,095 & 4.0 & 5,208 & 5.7 & 46,619 & 4.9 & 14,817 & 4.9 & 91,280 & 4.7 \\
\hline YLD (retinopathy) & 30,337 & 28.2 & 88,802 & 18.7 & 23,640 & 25.8 & 250,381 & 26.3 & 84,262 & 27.8 & 477,422 & 24.7 \\
\hline YLD (amputation) & 277 & 0.3 & 1,247 & 0.3 & 28 & 0.0 & 5,493 & 0.6 & 449 & 0.1 & 7,494 & 0.4 \\
\hline Total DALYs & 107,482 & 100.0 & 474,126 & 100.0 & 91,453 & 100.0 & 953,658 & 100.0 & 302,643 & 100.0 & $1,929,362$ & 100.0 \\
\hline
\end{tabular}

intensification of surveillance and control activities. Problems related to difficulties in access to health services and human resources training also need to be solved.

Mathers \& Loncar 36 prepared new mortality and burden of disease forecasts for 2030, based on WHO estimates for 2002. According to these authors, in 2002 diabetes mellitus was $11^{\text {th }}$ among the 15 main causes of death, and they predicted that by 2030 the disease would increase to 7 th place (3\% of total DALYs). According to their forecasts for 2030, diabetes mellitus is expected to occupy $4^{\text {th }}(4.8 \%), 6^{\text {th }}(3.7 \%)$, and 9 th places
(2.1\%), respectively, in high, medium, and lowincome countries.

Some potential limitations of the current study may lead to the underestimation of the burden of diabetes. The first relates to prevalence estimates for type I diabetes mellitus (which mainly affects children and adolescents and accounts for about $10 \%$ of cases), which was not included in the present study. As a matter of fact, some diabetes mellitus type I cases can occur later in life and may be confused with type II diabetes. Therefore, it is possible that some type I cases were unintentionally included in 
Absolute number of disability-adjusted life years (DALYs) estimated for 1998 and projected for 2013 and ranking of the four main causes of lost DALYs with the total increase for 15 years (1998-2013).

\begin{tabular}{|c|c|c|c|c|c|}
\hline \multirow[t]{2}{*}{ Gender/Disease categories } & \multicolumn{2}{|c|}{1998} & \multicolumn{2}{|c|}{2013} & \multirow{2}{*}{$\begin{array}{l}\text { Total 15-year } \\
\text { increase (\%) }\end{array}$} \\
\hline & Number of DALYs & Ranking & Number of DALYs & Ranking & \\
\hline \multicolumn{6}{|l|}{ Both sexes } \\
\hline All causes & $37,518,239$ & - & $40,177,049$ & - & 7.1 \\
\hline Diabetes mellitus & $1,929,362$ & 1 & $2,501,066$ & 1 & 29.6 \\
\hline Ischemic heart disease & $1,886,374$ & 2 & $1,959,036$ & 2 & 3.9 \\
\hline Stroke & $1,722,700$ & 3 & $1,799,143$ & 3 & 4.4 \\
\hline Recurrent depressive disorder & $1,439,654$ & 4 & $1,675,997$ & 4 & 16.4 \\
\hline \multicolumn{6}{|l|}{ Male } \\
\hline All causes & $20,221,071$ & - & $22,043,997$ & - & 9.0 \\
\hline Violence & $1,127,432$ & 1 & $1,211,694$ & 1 & 7.5 \\
\hline Diabetes mellitus & 887,002 & 4 & $1,198,351$ & 2 & 35.1 \\
\hline Ischemic heart disease & $1,125,769$ & 2 & $1,189,652$ & 3 & 5.7 \\
\hline Stroke & 938,656 & 3 & $1,004,468$ & 4 & 7.0 \\
\hline \multicolumn{6}{|l|}{ Female } \\
\hline All causes & $17,297,168$ & - & $18,133,052$ & - & 4.8 \\
\hline Diabetes mellitus & $1,042,360$ & 2 & $1,302,715$ & 1 & 25.0 \\
\hline Recurrent depressive disorder & $1,090,559$ & 1 & $1,239,262$ & 2 & 13.6 \\
\hline Stroke & 784,044 & 3 & 794,675 & 3 & 1.4 \\
\hline Ischemic heart disease & 760,605 & 4 & 769,384 & 4 & 1.2 \\
\hline
\end{tabular}

our estimations. On the other hand, we did not consider cases among adolescents and young adults, despite the recent increase in the prevalence of type II diabetes in this population. However, this limitation should be considered relatively less important, since type II diabetes accounts for some $90 \%$ of cases and typically affects "mature" adults (30 years or over), with a specific presentation and clinical evolution according to age group. The contrast between children/adolescents and "young" adults (30-44 years) is striking, with an important increase in the absolute and proportional number of DALY when moving from "young" adults (30-44 years) to "mature" adults (45-59 years).

The second potential limitation relates to the use of outdated prevalence rates for diabetes mellitus, since the last population-based multicenter study in Brazil was held in 1989. The blood glucose cutoff point used that year for defining an individual as diabetic was greater than or equal to $140 \mathrm{mg} / \mathrm{dL}$. This cutoff point was later reduced to $126 \mathrm{mg} / \mathrm{dL}$. Therefore, the global burden of disease related to diabetes mellitus is probably underestimated, since the prevalence rates used refer to 1989 .

The third potential limitation is the lack of nationwide clinical/epidemiological parameters for complications of the disease, since there are few population-based studies in Brazil that assess such complications.

In addition, due to the scarcity of data, some parameters for specific locations were expanded to an entire geographic region of the country. Another potential limitation was the underreporting of diabetes as the primary cause of death in the mortality information system.

Under-recording of diabetes mellitus in mortality statistics has been described frequently in the literature 37,38 . Studies show that in $40-60 \%$ of cases the disease is omitted from death certificates and is recorded as the primary cause in fewer than $10 \%$ 39,40,41. Global burden of disease studies do not use co-morbidities, and thus only use primary causes of death for each of the 113 problems and sequelae selected for the study. Diabetes mellitus was no exception to this rule. Global burden of disease research methods need to be developed to deal with co-morbidities.

An important point involves the distinct stages in the epidemiological transition in different regions of Brazil and their relation with the quality of the information systems. The Northeast region still presents conditions that affect loss of quality of life like "asphyxia and birth trauma" as compared to the other regions 
of Brazil, where non-communicable diseases (included in Group II) are more relevant. In addition, factors used to adjust for under-recording of deaths and the proportional distribution of ill-defined causes were also highest in the Northeast of Brazil, thus indicating worse quality in the morbidity and mortality information systems, besides an important delay in the reporting flow. This may have biased the estimates of global burden in these ares.

In recent decades, profound changes in diet quality and quantity, together with reduced physical activity in the overall population, have led to an increase in the prevalence of diabetes and its complications, and in turn to high costs for health systems 42 and increased suffering for thousands of individuals. This increase in diabetes thus represents an additional burden for society due to decreased work productivity, early retirement, and premature death ${ }^{4}$.

Given that approximately $50 \%$ of individuals with diabetes mellitus are unaware of their diagnosis, $20-30 \%$ of patients who know their diagnosis lack treatment or follow-up $43,44,68 \%$ of known cases are diagnosed by chance or due to some clinical manifestation of late complications 43 , and $50-78 \%$ had poor blood glucose control 45,46, effective measures are urgently needed to reduce this public health problem and ensure prevention, early diagnosis, with adequate and comprehensive counseling and treatment for patients with diabetes mellitus.

\section{Resumo}

O diabetes mellitus tipo II é responsável por 90\% de todos os casos de diabetes, e sua inclusão na avaliação de saúde evidencia que as suas complicações têm um considerável impacto na qualidade de vida de uma população. O presente artigo apresenta os resultados do Estudo de Carga Global de Doença, realizado no Brasil para o ano de 1998, com ênfase no diabetes mellitus e suas complicações. O indicador utilizado foi o disability-adjusted life years (DALY), ao qual aplicou-se a taxa de desconto de 3\%. No Brasil, doenças isquêmicas do coração, doenças cardiovasculares e diabetes contribuíram com 14,7\% do total de DALY. Observou-se uma maior participação do years lived with disability (YLD) no total de DALY para o diabetes quando comparado a outros países. As complicações retinopatias e neuropatias foram as que mais contribuíram para o YLD. Projeções indicam que o diabetes mellitus terá crescente impacto sobre a perda de anos de vida por morte prematura e incapacidade no mundo, e que se deslocará de 11a para 7a causa de morte em 2030. Faz-se urgente a implantação e implementação de medidas efetivas para prevenção, diagnóstico precoce, aconselhamento e adequado acompanhamento dos pacientes com diabetes mellitus.

Diabetes Mellitus; Anos Potenciais de Vida Perdidos; Efeitos Psicossociais da Doença

\section{Contributors}

A. F. Oliveira conducted the literature search strategy and analysis of the available data and interpretation. J. G. Valente performed the analysis and commented on the analysis and interpretation. I. C. Leite, J. M. A. Schramm, A. S. R. Azevedo, and A. M. J. Gadelha commented on the analysis and interpretation. 


\section{References}

1. Sociedade Brasileira de Diabetes. Consenso Brasileiro sobre Diabetes 2002: diagnóstico e classificação do diabetes melito e tratamento do diabetes melito tipo 2. Rio de Janeiro: Diagraphic Editora; 2003.

2. Organización Panamericana de la Salud. La diabetes en las Américas. Bol Epidemiol (Wash) 2001; 22:1-3.

3. Barceló A, Rajpathak S. Incidence and prevalence of diabetes mellitus in the Americas. Rev Panam Salud Pública 2001; 10:300-8.

4. World Health Organization. The World Health Report 2002: reducing risks, promoting healthy life. Geneva: World Health Organization; 2002.

5. Willett WC, Koplan JP, Nugent R, Dusenbury C, Puska P, Gaziano TA. Prevention of chronic disease by means of diet and lifestyle changes. In: Jamison DT, Breman JG, Measham AR, Alleyne G, Claeson M, Evans DB, et al., editors. Disease control priorities in developing countries. New York: World Bank/ Oxford University Press; 2006. p. 833-50.

6. Rodgers A, Lawes CMM, Gaziano T, Vos T. The growing burden of risk from high blood pressure, cholesterol, and bodyweight. In: Jamison DT, Breman JG, Measham AR, Alleyne G, Claeson M, Evans DB, et al., editors. Disease control priorities in developing countries. New York: World Bank/Oxford University Press; 2006. p. 851-68.

7. Santos AM. Diagnóstico do diabete melito, drogas utilizadas no tratamento e terapia combinada. In: Luna RL, Sabra A, organizadores. Medicina de família: saúde do adulto e do idoso. Rio de Janeiro: Editora Guanabara Koogan; 2006. p. 849-57.

8. Toscano CM. As campanhas nacionais para detecção das doenças crônicas não-transmissíveis: diabetes e hipertensão arterial. Ciênc Saúde Coletiva 2004; 9:885-95.

9. Oliveira JEP, Monteiro JB, Araújo CGS. Diabetes melito tipo 2: terapêutica clínica prática. Rio de Janeiro: Medline; 2003.

10. Nayaran KM, Gregg EW, Fagot-Campagna A, Engelgau MM, Vinicor F. Diabetes: a common, growing, serious, costly and potentially preventable public health problem. Diabetes Res Clin Pract 2000; 50 Suppl 2:S77-84.

11. King H, Aubert RE, Herman WH. Global burden of diabetes, 1995-2025: prevalence, numerical estimates, and projections. Diabetes Care 1998; 21:1414-31.

12. Gruber W, Lander T, Leese B, Songer T, Williams R. The economics of diabetes and diabetes care. A report of the Diabetes Health Economics Study Group. Brussels: International Diabetes Federation; 1998.

13. Malerbi DA, Franco LJ. Multicenter study of the prevalence of diabetes mellitus and impaired glucose tolerance in the urban Brazilian population aged 30-69 yr. The Brazilian Cooperative Group on the Study of Diabetes Prevalence. Diabetes Care 1992; 5:1509-16.

14. Centers for Disease Control and Prevention. Diabetes-related amputations of lower extremities in the Medicare population: Minnesota, 1993-1995. MMWR Morb Mortal Wkly Rep 1998; 47:649-52.
15. Brand FN, Abbott RD, Kannel WB. Diabetes, intermittent claudication, and risk of cardiovascular events. The Framingham Study. Diabetes 1989; 38:504-9.

16. Gu K, Cowie CC, Harris MI. Mortality in adults with and without diabetes in a national cohort of the U.S. population, 1971-1993. Diabetes Care 1998; 21:1138-45.

17. Haffner SM. Coronary heart disease in patients with diabetes. N Engl J Med 2000; 342:1040-2.

18. Hayden JM, Reaven PD. Cardiovascular disease in diabetes mellitus type 2: a potential role for novel cardiovascular risk factors. Curr Opin Lipidol 2000; 11:519-28.

19. Kanters SD, Banga JD, Stolk RP, Algra A. Incidence and determinants of mortality and cardiovascular events in diabetes mellitus: a meta-analysis. Vasc Med 1999; 4:67-75.

20. United States Renal Data System. Executive summary of United States Renal Data System, 19941999. http://www.usrds.org (accessed on 20/ Oct/2007).

21. Johnson PC, Doll SC, Cromey DW. Pathogenesis of diabetic neuropathy. Ann Neurol 1986; 19:450-7.

22. Levin ME. Foot lesions in patients with diabetes mellitus. Endocrinol Metab Clin North Am 1996; 25:447-62.

23. World Health Organization. Diet, nutrition and the prevention of chronic diseases. Geneva: World Health Organization; 2003.

24. Murray CJL, Lopez AD. Global comparative assessments in the health sector. Geneva: World Health Organization; 1994.

25. Dasgupta P, Sem A, Marglin S. Guidelines for project evaluation. New York: United Nations; 1972.

26. Layard R, Glaister S. Cost-benefit analysis. Cambridge: Cambridge University Press; 1994.

27. Lind RC, Stiglitz JE, Wilson R, Dasgupta P, Stockfisch JA. Discounting for time and risk in energy policy. Baltimore: Johns Hopkins University Press; 1982.

28. Gold MR, Siegel JE, Weinstein MC, Russell LB. Cost-effectiveness in health and medicine. New York: Oxford University Press; 1996.

29. Organização Mundial da Saúde. Classificação estatística internacional de doenças e problemas relacionados à saúde, 10a revisão. v. 1. São Paulo: Edusp; 1997.

30. Leite IC, Beltrão KI, Rodrigues RN, Valente JG, Campos MR, Schramm JMA. Projeção da carga de doença no Brasil (1998-2013). In: Buss PM, Temporão JG, Carvalheiro JR, organizadores. Vacinas, soros e imunizações no Brasil. Rio de Janeiro: Editora Fiocruz; 2005. p. 51-65.

31. Murray CJL, Lopez AD. The global burden of disease: a comprehensive assessment of mortality and disability from diseases, injuries, and risk factors in 1990 and projected to 2020. Harvard: Harvard School of Public Health; 1996.

32. Pomerleau J, McKee M, Lobstein T, Knai C. The burden of disease attributable to nutrition in Europe. Public Health Nutr 2003; 6:453-61. 
33. Mathers C, Vos T, Stevenson C. The burden of disease and injury in Australia: summary report. Canberra: Australian Institute of Health and Welfare; 1999.

34. Melse JM, Essink-Bot ML, Kramers PG, Hoeymans N. A national burden of disease calculation: Dutch disability-adjusted life-years. Dutch Burden of Disease Group. Am J Public Health 2000; 90:1241-7.

35. Lopez AD, Mathers CD, Ezzati M, Jamison DT, Murray CJL. Global burden of disease and risk factors. Washington DC: World Bank/New York: Oxford University Press; 2006.

36. Mathers CD, Loncar D. Projections of global mortality and burden of disease from 2002 to 2030 . PLoS Med 2006; 3:e442.

37. Melo MS, Lolio CA, Lucena MAF, Kirzner CF, Martins SM, Barros MNDS. Causas múltiplas de morte em diabéticos no município de Recife, 1987. Rev Saúde Pública 1991; 25:435-42.

38. Lessa I, Silva MRB, Cardeal CM. Mortalidade proporcional pelo diabetes mellitus como causa básica e associada de morte nos espaços sociais da cidade Salvador, Brasil. Rev Baiana Saúde Pública 1991; 18:75-84.

39. Andresen EM, Lee JA, Pecoraro RE, Koepsell TD, Hallstrom AP, Siscovick DS. Underreporting of diabetes on death certificates, King Country, Washington. Am J Public Health 1993; 83:1021-4.

40. Gatling W, Tufail S, Mullee MA, Westacott TA, Hill RD. Mortality rates in diabetic patients from a community-based population compared to local age/sex matched controls. Diabet Med 1997; 14:316-20.

41. Ochi JW, Melton LJ, Palumbo PJ, Chu CA. A population based study of diabetes mortality. Diabetes Care 1985; 8:224-9.

42. Boutayeb A, Boutayeb S. The burden of non-communicable diseases in developing countries. Int J Equity Health 2005; 4:1-8.

43. Gagliardino JJ, Olivera EM, Barragán HL, Hernández RE. Diabetes mellitus e hipertensión arterial: aspectos clínicos y epidemiológicos en la población de La Plata. Medicina (B. Aires) 1995; 55: 421-30.
44. Gagliardino JJ, Olivera E. The regions and their health care systems: Latin America. In: Gruber W, Lander T, Leese B, Songer T, Williams H, editors. Economics of diabetes and diabetes care. A report of the Diabetes Health Economics Study Group. Brussels: International Diabetes Federation/Geneva: World Health Organization; 1997. p. 51-9.

45. Assunção MCF, Santos IS, Valle NCJ. Blood glucose control in diabetes patients seen in primary health care centers. Rev Saúde Pública 2005, 39:183-90.

46. Lopez-Stewart G, Tambascia M, Rosas-Guzmán J, Etchegoyen F, Ortega-Carrión J, Artemenko S. Control of type 2 diabetes mellitus among general practitioners in private practice in nine countries of Latin America. Rev Panam Salud Pública 2007; 22:12-20

47. Bennett JC, Plum F. Cecil: tratado de medicina interna. 20a Ed. Rio de Janeiro: Editora Guanabara Koogan; 1997.

48. Williams RH. Textbook of endocrinology. $5^{\text {th }}$ Ed. Philadelphia: W. B. Saunders Co.; 1974.

49. Ulson ACB, Abujamra S. Análise de 400 pacientes diabéticos portadores de retinopatia. Arq Bras Oftalmol 1986; 49:9-12.

50. Bernardes CHA, Penteado JG, Martins MF, Rosa VA, Tinós MS. Pé diabético: análise de 105 casos. Arq Bras Endocrinol Metab 1993; 37:139-42.

51. Franco LJ, Milech A, Pimazoni Neto A, Braga CDC, Malerbi D, Campos GP, et al. Estudo multicêntrico sobre a prevalência do diabetes mellitus no Brasil. Inf Epidemiol SUS 1992; 1:47-73.

52. Almeida AAL, Bonfante HLM, Moreira RO, Arbex AK, Souza GS, Maciel LG, et al. Perfil epidemiológico do diabetes mellitus auto-referido em uma zona urbana de Juiz de Fora, Minas Gerais. Arq Bras Endocrinol Metab 1999; 43:199-204.

53. Muggeo M, Verlato G, Bonora E. The Verona diabetes study: a population-based survey on known diabetes mellitus prevalence and 5-year all-cause mortality. Diabetologia 1995; 38:318-25.

Submitted on 18/Jan/2008

Final version resubmitted on 11/Jun/2008

Approved on 01/Jul/2008 